Шип Д.Я.

\title{
Аналіз виявлення зниження гостроти слуху у дітей різних вікових категорій Закарпаття під час профілактичних оглядів
}

\author{
ДВНЗ «Ужгородський національний університет», м. Ужгород, Україна \\ eulifeshyp@gmail.com
}

\begin{abstract}
Шип Д.Я.
Анализ выявление снижение остроты слуха у детей разных возрастных категорий Закарпатья при профилактических осмотрах

ГВУЗ «Ужгородский национальный университет», г. Ужгород, Украина
\end{abstract}

Shyp D.Y.

Analysis of detection of hearing acute reduction of children of different age categories of Transcarpathia during preventive examinations Uzhhorod national university, Uzhhorod, Ukraine

\section{Встуі}

Згідно зі світовою статистикою, порушення слуху є найпоширенішою патологією у новонароджених. Одна-дві дитини з тисячі народжуються із серйозними порушеннями слуху або з глухотою, ще у двох-чотирьох дітей спостерігається середній ступінь порушення слуху [1].

Відомо, що стійке порушення слухового аналізатора призводить до суттєвих відхилень в мовному розвитку дитини, негативно впливає на психічний стан особистості, обмежує можливості пізнання оточуючого світу, оволодіння знаннями, вміннями, навичками, перешкоджає повноцінному словесному спілкуванню 3 оточуючими. Отже, зниження слуху означає не лише нездатність чути звуки. Патологія аудіальної системи може суттєво впливати на анатомічний, фізіологічний і психологічний розвиток, a, відповідно, і на формування особистості дитини [2,3].

В переважній більшості дитина яка погано чує не може оволодіти усним мовленням. У той же час, нормальний рівень володіння мовою - необхідний фактор для досягнення належного рівня інтелектуального, емоційного і соціального розвитку. Це також $є$ підставою для входження дитини в співтовариство чуючих людей та відкриває їй шлях до інклюзії та інтеграції. В результаті дитина отримує якісну освіту і в майбутньому буде мати високі шанси на працевлаштування відповідно до своєї кваліфікації. Це складе основу для високої самооцінки i достатнього рівня самореалізації i, таким чином, допоможе досягти кращої якості життя [4,5].

Мета - дослідити та проаналізувати частоту виявлення зниження гостроти слуху у дітей різних вікових категорій Закарпаття під час профілактичних оглядів.

\section{Матеріали та методи}

Матеріалами дослідження слугували результати профілактичних оглядів дітей різних вікових категорій
Закарпатської області в розрізі адміністративних територій за період 2016-2017 pp. В ході дослідження використано статистичний метод.

\section{Результати дослідження та їх обговорення}

На початку дослідження було вивчено та проаналізовано дані щодо частоти виявлення зниження гостроти слуху при профілактичних оглядах дітей віком 017 років включно в розрізі адміністративних територій області в розрахунку на 1000 оглянутих дітей. Отримані результати наведено в табл. 1.

Аналіз наведених в табл. 1 даних вказує на те, що частота виявлення зниження гостроти слуху при профілактичних оглядах дітей віком 0-17 років включно має тенденцію до зниження (за два роки дослідження на 0,2 на 1000 оглянутих). В 2016 р. найбільша частка виявленої патології була зареєстрована в Мукачівському районі $(3,3)$, а найменша - в м. Ужгород $(0,2)$. Гранична різниця показника в межах адміністративних територій становила 16,5 разу. В 2017 р. найбільша частка виявленої патології була зареєстрована теж в Мукачівському районі $(3,6)$, а найменша - в м. Ужгород $(0,3)$. Гранична різниця показника в межах адміністративних територій становила 12,0 разів. При цьому за період дослідження в В.Березнянському районі дітей із зниженим слухом під час профілактичних оглядів виявлено не було. В 2017 р. середній показник частоти виявлення зниження гостроти слуху при профілактичних оглядах дітей віком 0-17 років включно по області становив 1,4 на 1000 оглянутих дітей при відповідному показнику по країні - 1,74.

Далі вивчалися та аналізувалися дані щодо частоти виявлення зниження гостроти слуху при профілактичних оглядах дітей дошкільного віку. Отримані дані наведено в табл. 2. 
Таблиця 1. Частота виявлення зниження гостроти слуху при профілактичних оглядах дітей віком 0-17 років включно, 2016-2017 рр. (на 1000 оглянутих)

\begin{tabular}{|l|c|c|c|c|}
$\begin{array}{l}\text { Адміністративна } \\
\text { територія }\end{array}$ & \multicolumn{2}{c|}{$\begin{array}{c}\text { Оглянуто } \\
\text { дітей всього }\end{array}$} & \multicolumn{2}{|c|}{$\begin{array}{c}\text { 3і зниженням } \\
\text { гостроти слуху }\end{array}$} \\
\hline м. Ужгород & $\mathbf{2 0 1 6}$ & $\mathbf{2 0 1 7}$ & $\mathbf{2 0 1 6}$ & $\mathbf{2 0 1 7}$ \\
\hline м. Мукачево & 22599 & 22383 & 0,2 & 0,3 \\
\hline Берегівський & 18250 & 18526 & 1,4 & 1,6 \\
\hline В.Березнянський & 6142 & 6174 & - & - \\
\hline Виноградівський & 30679 & 30683 & 1,8 & 1,5 \\
\hline Воловецький & 4935 & 5156 & 3,0 & 2,3 \\
\hline Іршавський & 21991 & 21578 & 0,5 & 0,6 \\
\hline Міжгірський & 11472 & 11477 & 1,2 & 0,9 \\
\hline Мукачівський & 23137 & 23376 & 3,3 & 3,6 \\
\hline Перечинський & 8375 & 8508 & 1,8 & 2,0 \\
\hline Рахівський & 24417 & 24482 & 2,4 & 2,5 \\
\hline Свалявський & 12610 & 12761 & 1,6 & 1,4 \\
\hline Тячівський & 35611 & 41362 & 1,6 & 1,0 \\
\hline Ужгородський & 17475 & 17739 & 1,4 & 0,6 \\
\hline Хустський & 29528 & 29639 & 1,4 & 1,2 \\
\hline ВСьОГО & 283237 & 289717 & 1,6 & 1,4 \\
\hline
\end{tabular}

Таблиця 2. Частота виявлення зниження гостроти слуху при профілактичних оглядах дітей дошкільного віку, 2016-2017 рр. (на 1000 оглянутих)

\begin{tabular}{|l|c|c|c|c|}
\hline $\begin{array}{c}\text { Адміністративна } \\
\text { територія }\end{array}$ & \multicolumn{2}{|c|}{$\begin{array}{c}\text { Оглянуто } \\
\text { дітей всього }\end{array}$} & \multicolumn{2}{|c|}{ Зі зниженням } \\
\hline гостроти слуху
\end{tabular}

Проведений аналіз наведених в табл. 2 даних вказує на тенденцію до зменшення частоти виявлення зниження гостроти слуху при профілактичних оглядах дітей дошкільного віку (на 0,1 на 1000 оглянутих дітей за період
2016-2017 рр.). В 2016 році найбільша частка виявленої патології була зареєстрована в Міжгірському районі $(1,6)$, a найменша - в м. Ужгород $(0,1)$. Гранична різниця показника в межах адміністративних територій становила 16,0 разів. В 2017 році найбільша частка виявленої патології була зареєстрована в м.Мукачево $(1,4)$, а найменша - в Ужгородському районі $(0,3)$. Гранична різниця показника в межах адміністративних територій становила 4,7 разу. При цьому за період дослідження в В.Березнянському та Воловецькому районах дітей даної вікової категорії із зниженим слухом під час профілактичних оглядів виявлено не було. В 2017 році середній показник частоти виявлення зниження гостроти слуху при профілактичних оглядах дітей дошкільного віку по області становив 0,6 на 1000 оглянутих дітей при відповідному показнику по країні - 0,91.

Наступним кроком дослідження було вивчення та проведення аналізу частоти виявлення зниження гостроти слуху при профілактичних оглядах дітей, що почали навчання з 6 років. Отримані дані наведено в табл. 3 .

Таблиця 3. Частота виявлення зниження гостроти слуху при профілактичних оглядах дітей, що почали навчання 36 років, 2016-2017 рр. (на 1000 оглянутих)

\begin{tabular}{|l|c|c|c|c|}
\hline $\begin{array}{l}\text { Адміністративна } \\
\text { територія }\end{array}$ & \multicolumn{2}{|c|}{$\begin{array}{c}\text { Оглянуто } \\
\text { дітей всього }\end{array}$} & \multicolumn{2}{|c|}{$\begin{array}{c}\text { 3і зниженням } \\
\text { гостроти слуху }\end{array}$} \\
\hline м. Уж16 & $\mathbf{2 0 1 7}$ & $\mathbf{2 0 1 6}$ & $\mathbf{2 0 1 7}$ \\
\hline м. Мукород & 932 & 966 & 1,1 & - \\
\hline Берегівський & 823 & 836 & - & 1,2 \\
\hline В.Березнянський & 267 & 291 & - & - \\
\hline Виноградівський & 1521 & 1484 & 2,0 & 0,7 \\
\hline Воловецький & 287 & 254 & 3,5 & 3,9 \\
\hline Іршавський & 1299 & 1273 & - & 0,8 \\
\hline Міжгірський & 675 & 651 & 3,0 & - \\
\hline Мукачівський & 1124 & 1147 & 4,4 & 7,8 \\
\hline Перечинський & 364 & 392 & 2,7 & - \\
\hline Рахівський & 1231 & 1512 & 3,2 & 2,6 \\
\hline Свалявський & 757 & 787 & 1,3 & - \\
\hline Тячівський & 2574 & 2709 & 3,5 & 1,8 \\
\hline Ужгородський & 1105 & 1105 & - & 0,9 \\
\hline Хустський & 1736 & 1740 & 1,2 & 1,1 \\
\hline ВСьОГО & 15498 & 15899 & 2,0 & 1,6 \\
\hline
\end{tabular}

Проведений аналіз наведених в табл.3 даних вказує на тенденцію до зменшення частоти виявлення зниження гостроти слуху при профілактичних оглядах дітей, що почали навчання 36 років (на 0,4 на 1000 оглянутих дітей за період 2016-2017 рр.). В 2016 р. найбільша частка виявленої патології була зареєстрована в Мукачівському районі $(4,4)$, а найменша - в м. Ужгород $(1,1)$. При цьому в 4 районах дана патологія не була виявлена. Гранична різниця показника в межах адміністративних територій становила 4,0 разів. В 2017 р. найбільша частка виявленої патології була зареєстрована в Мукачівському районі 
$(7,8)$, а найменша - в Виноградівському районі $(0,7)$. Гранична різниця показника в межах адміністративних територій становила 11,1 разу. При цьому в 5 адміністративних територіях дана патологія не була виявлена. В 2017 р. середній показник частоти виявлення зниження гостроти слуху при профілактичних оглядах дітей, що почали навчання з 6 років по області становив 1,6 на 1000 оглянутих дітей при відповідному показнику по країні - 2,27.

Далі було вивчено та проаналізовано дані про частоту виявлення зниження гостроти слуху при профілактичних оглядах дітей, що почали навчання 7 років. Отримані результати наведено в табл. 4.

Таблиця 4. Частота виявлення зниження гостроти слуху при профілактичних оглядах дітей, що почали навчання 37 років, 2016-2017 рр. (на 1000 оглянутих)

\begin{tabular}{|l|c|c|c|c|c|}
\hline \begin{tabular}{|l|c|c|} 
Адміністративна \\
територія
\end{tabular} & \multicolumn{2}{|c|}{$\begin{array}{c}\text { Оглянуто } \\
\text { дітей всього }\end{array}$} & \multicolumn{2}{c|}{ Зі зниженням } \\
\hline & $\mathbf{2 0 1 6}$ & $\mathbf{2 0 1 7}$ & $\mathbf{2 0 1 6}$ & $\mathbf{2 0 1 7}$ \\
\hline м. Ужгород & 521 & 407 & 1,9 & - \\
\hline м. Мукачево & 219 & 373 & - & - \\
\hline Берегівський & 175 & 167 & 11,4 & 6,0 \\
\hline В.Березнянський & 45 & 55 & - & - \\
\hline Виноградівський & 222 & 215 & - & - \\
\hline Воловецький & 12 & 22 & 83,3 & - \\
\hline Іршавський & 133 & 162 & - & - \\
\hline Міжгірський & 206 & 220 & 4,9 & - \\
\hline Мукачівський & 315 & 306 & 9,5 & 16,3 \\
\hline Перечинський & 80 & 91 & - & - \\
\hline Рахівський & 218 & 48 & 4,6 & - \\
\hline Свалявський & 25 & 24 & - & - \\
\hline Тячівський & 35 & 28 & 114,3 & 107,1 \\
\hline Ужгородський & 576 & 146 & 1,7 & - \\
\hline Хустський & 137 & 130 & - & - \\
\hline ВСьОГО & 2919 & 2394 & 4,8 & 3,8 \\
\hline & & & & \\
\hline
\end{tabular}

Проведений аналіз наведених в табл. 4 даних вказує на тенденцію до зменшення частоти виявлення зниження гостроти слуху при профілактичних оглядах дітей, що почали навчання 37 років ( на 1,0 на 1000 оглянутих дітей за період 2016-2017 pp). В 2016 році найбільша частка виявленої патології була зареєстрована в Тячівському районі $(114,3)$, а найменша - в м. Ужгород $(1,9)$. При цьому в 7 районах дана патологія не була виявлена. Гранична різниця показника в межах адміністративних територій становила 60,2 разу. В 2017 році найбільша частка виявленої патології була зареєстрована теж в Тячівському районі $(107,1)$, а найменша - в Берегівському районі $(6,0)$. Гранична різниця показника в межах адміністративних територій становила 17,9 разу. При цьому в 13 адміністративних територіях дана патологія не була виявлена. В 2017 році середній показник частоти виявлення зниження гостроти слуху при профілактичних оглядах дітей, що почали навчання 37 років по області становив 3,8 на 1000 оглянутих дітей при відповідному показнику по країні - 3,32. Вказана різниця показників в розрізі адміністративних територій області потребує поглибленого вивчення причин.

Наступним кроком дослідження було вивчення та проведення аналізу частоти виявлення зниження гостроти слуху при профілактичних оглядах школярі 9-11 класів. Отримані дані наведено в табл. 5.

\section{Таблиця 5. Частота виявлення зниження гостроти слуху при профілактичних оглядах школярів 9-11 класів, 2016-2017 pp. (на 1000 оглянутих)}

\begin{tabular}{|l|c|c|c|c|}
\hline \begin{tabular}{l} 
Адміністративна \\
\multicolumn{1}{|c|}{ територія }
\end{tabular} & \multicolumn{2}{|c|}{$\begin{array}{c}\text { Оглянуто } \\
\text { дітей всього }\end{array}$} & \multicolumn{2}{|c|}{ 3і зниженням } \\
гостроти слуху
\end{tabular}

Проведений аналіз наведених в табл. 5 даних вказує на тенденцію до зростання частоти виявлення зниження гостроти слуху при профілактичних оглядах школярів 911 класів на 0,5 на 1000 оглянутих дітей за період 20162017 рр.). В 2016 р. найбільша частка виявленої патології була зареєстрована в Перечинському районі $(3,5)$, а найменша - в Міжгірському районі $(0,5)$. При цьому в 2 районах дана патологія не була виявлена. Гранична різниця показника в межах адміністративних територій становила 7,0 разів. В 2017 році найбільша частка виявленої патології була зареєстрована в Воловецький районі $(19,4)$, а найменша - в Іршавському районі $(0,5)$. Гранична різниця показника в межах адміністративних територій становила 38,8 разу. При цьому в В.Березнянському районі в 2017 р. дана патологія не була виявлена.

Перспективи подальших досліджень пов'язані 3 вивченням спроможності системи охорони здоров'я Закарпатської області забезпечити дітей з пониженим слухом необхідною медичною допомогою. 


\section{Висновки}

В ході дослідження встановлено, що частота виявлення зниження гостроти слуху у дітей різних вікових категорій, крім школярів 9-11 класів, де відмічено зростання показника, Закарпатської області під час профілактичних оглядів має тенденцію до скорочення, але залишається високою. Встановлені значні коливання зазначеного показника в розрізі адміністративних територій. Так, найвищий показник виявлення вказаної патології зареєстровано серед дітей, що почали навчання 3 7 років в Тячівському районі (114,3 в розрахунку на 1000 оглянутих) в той час як в 7 районах області серед дітей даної вікової категорії вказана патологія не була виявлена.

Виявлені під час профілактичних оглядів високі показники частоти зниження гостроти слуху у дітей потребують забезпечення дітей спеціалізованою медичною допомогою та спеціальними умовами навчання.

\section{Література}

1. Ленхардт М. Универсальный неонатальный скрининг слуха: обязательный, факультативный или излишний? // Доклад на Конгрессе отоларингологов в Ереване 23 ноября 2010 г. - С. 3, 9-10.

2. Дитина зі світу тиші: на допомогу батьками нечуючої дитини : наук.-метод. посіб. / Укл. Н. А. Зборовська та ін.; за ред. С. В. Кульбіди. - К. : СПКТБ УТОГ, 2011. - 183 с.

3. Мороз Б. С. Корекційні технології у слухопротезуванні дітей / Б. С. Мороз, В. П. Овсяник, К. В. Луцько. К. : Науково-методисне підприсмство, 2008. - 14 с.

4. Янн П. Значение и возможности обучения слуховому восприятию после кохлеарной имплантации // Актуальные вопросы логопатологии. Сб. статей. / Под ред. И.В. Королевой. - СПб., 2004. - С. 119, 121.

5. Рахманов В. М. Медико-социальные аспекты воспитания и обучения детей с нарушениями слуха / В. М. Рахманов. - Х. : Основа, 1990. -153 с.

\section{References}

1. Lenhardt M. Universal'nyj neonatal'nyj skrining sluha: obyazatel'nyj, fakul'tativnyj ili izlishnij? // Doklad na Kongresse otolaringologov v Erevane 23 noyabrya 2010 g. - S. 3, 9-10.

2. Dytyna zi svitu tyshi: na dopomohu batkamy nechuiuchoi dytyny : nauk.-metod. posib. / Ukl. N. A. Zborovska ta in.; za red. S. V. Kulbidy. - K. : SPKTB UTOH, 2011. $-183 \mathrm{~s}$.

3. Moroz B. S. Korektsiini tekhnolohii u slukhoprotezuvanni ditei / B. S. Moroz, V. P. Ovsianyk, K. V. Lutsko. K. : Naukovo-metodysne pidpryiemstvo, 2008. $-14 \mathrm{~s}$.

4. Yann P. Znachenie i vozmozhnosti obucheniya sluhovomu vospriyatiyu posle kohlearnoj implantacii // Aktual'nye voprosy logopatologii. Sb. statej. / Pod red. I.V. Korolevoj. - SPb., 2004. - C.119, 121.

5. Rahmanov V. M. Mediko-social'nye aspekty vospitaniya $i$ obucheniya detej s narusheniyami sluha / V. M. Rahmanov. - H.: Osnova, 1990. - 153 s.

Дата надходження рукопису до редакції: 20.07.2020 p.

Мета - дослідити та проаналізувати частоту виявлення зниження гостроти слуху у дітей різних вікових категорій Закарпаття під час профілактичних оглядів.

Матеріали та методи. Матеріалами дослідження слугували результати профілактичних оглядів дітей різних вікових категорій Закарпатської області в розрізі адміністративних територій за період 2016-2017 pр. В ході дослідження використано статистичний метод.

Результати. В ході дослідження встановлено, що частота виявлення зниження гостроти слуху у дітей різних вікових категорій, крім школярів 9-11 класів, де відмічено зростання показника, Закарпатської області під час профілактичних оглядів має тенденцію до скорочення, але залишається високою. Встановлені значні коливання зазначеного показника в розрізі адміністративних територій. Так, найвищий показник виявлення вказаної патології зареєстровано серед дітей, що почали навчання з 7 років в Тячівському районі (114,3 в розрахунку на 1000 оглянутих) в той час як в 7 районах області серед дітей даної вікової категорії вказана патологія не була виявлена.

Висновки. Виявлені під час профілактичних оглядів високі показники частоти зниження гостроти слуху у дітей потребують їх забезпечення спеціалізованою медичною допомогою та спеціальними умовами навчання.

Ключові слова: Закарпатська область, діти, зниження гостроти слуху, профілактичні огляди, частота.

Цель - исследовать и проанализировать частоту выявления снижения остроты слуха у детей разных возрастных категорий Закарпатье во время профилактических осмотров. 
Материалы и методы. Материалами исследования послужили результаты профилактических осмотров детей разных возрастов Закарпатской области в разрезе административных территорий за период $2016-2017$ гг. В ходе исследования использован статистический метод.

Результаты. В ходе исследования установлено, что частота выявления снижения остроты слуха у детей разных возрастных категорий, кроме школьников 9-11 классов, где отмечен рост показателя Закарпатской области во время профилактических осмотров имеет тенденцию к сокращению, но остается высокой. Установлены значительные колебания указанного показателя в разрезе административных территорий. Так, самый высокий показатель выявления данной патологии зарегистрировано среди детей, начавших обучение с 7 лет в Тячевском районе (114,3 в расчете на 1000 осмотренных) в то время как в 7 районах области среди детей данной возрастной категории указана патология не была выявлена.

Выводы. Обнаруженные во время профилактических осмотров высокие показатели частоты снижение остроты слуха у детей нуждаются в их обеспечение специализированной медицинской помощью и специальными условиями обучения.

Ключевые слова: Закарпатская область, дети, снижение остроты слуха, профилактические осмотры, частота.

Purpose: to study and analyze the frequency of detecting a reduction in hearing acuity of children of different age categories in Transcarpathia during preventive examinations.

Materials and methods. The research materials were the results of preventive examinations of children of different ages in the Transcarpathian region in the context of administrative territories for the period 2016-2017. The study used a statistical method.

Results. The study found that the frequency of hearing loss of children of different ages, except for students in grades 9-11, where there was an increase in the rate, Transcarpathian region during preventive examinations tends to decrease, but remains high. Significant fluctuations of the specified indicator in the context of administrative territories are established. Thus, the highest rate of detection of this pathology was registered among children who started school at the age of 7 in Tyachiv district (114.3 per 1,000 examined), while in 7 districts of the region among children of this age this pathology was not detected.

Conclusions. The high rates of hearing loss of children identified during preventive examinations require their provision of specialized medical care and special training conditions.

Key words: Transcarpathian region, children, hearing acuity reduction, preventive examinations, frequency.

\section{Відомості про автора}

Шип Денис Ярославович - асистент кафедри громадського здоров’я та гуманітарних дисциплін ДВНЗ «Ужгородський національний університет»; м. Ужгород, вул. Університетська 14.

eulifeshyp@gmail.com. 